\title{
Agronomic performance of onion cultivars as affected by phosphate fertilization ${ }^{1}$
}

\author{
Luiz Ricardo Rebouças da Silva², Leilson Costa Grangeiro ${ }^{*}$ (D), Valdívia de Fatima Lima de Sousa ${ }^{2}$, \\ Francisco Irael de Souza ${ }^{2}$,Francisco das Chagas Gonçalves ${ }^{2}$, Gardênia Silvana Rodrigues de Oliveira ${ }^{2}$
}

\author{
10.1590/0034-737X202168050001
}

\begin{abstract}
Phosphorus (P) is an important nutrient for obtaining high yields and has been the one that most often limits production. The objective of this study was to evaluate the agronomic performance of onion cultivars as a function of phosphate fertilization. The experiments were installed at the Rafael Fernandes Experimental Farm, of the Federal Rural University of the Semi-Arid Region, Mossoró-RN, Brazil, from July to October 2016 and from June to October 2017. The design used was randomized blocks, in a 2 x 6 factorial scheme, with four replicates. The treatments consisted of the combination of two onion cultivars (IPA11 and Rio das Antas) and six P doses (0, 60, 120, 180, 240 and $\left.300 \mathrm{~kg} \mathrm{ha}^{-1} \mathrm{P}_{2} \mathrm{O}_{5}\right)$. The economical doses of $\mathrm{P}$, associated with the maximum marketable yields of onion were estimated at 212.45 and $207.65 \mathrm{~kg} \mathrm{ha}^{-1}$ of $\mathrm{P}_{2} \mathrm{O}_{5}$, respectively for the cultivars IPA 11 and Rio das Antas. In general, the cultivar Rio das Antas was more productive than IPA 11, in the two growing periods.
\end{abstract}

Keywords: Allium cepa L.; plant mineral nutrition; yield.

\section{INTRODUCTION}

Onion (Allium cepa L.) is a vegetable of great national importance as it occupies the third place in volume and income generated among the vegetable crops, only surpassed by potatoes and tomatoes. In 2018, the area cultivated with onions in Brazil was 48,600 hectares and its production reached 1.55 million tons, with an average yield of $32 \mathrm{t} \mathrm{ha}^{-1}$. The South region accounted for $61.2 \%$ of the national production, followed by the Southeast (17.0\%), Northeast (16.0\%), and Midwest (5.3\%) (IBGE, 2018). In Rio Grande do Norte, onion cultivation was established less than a decade ago, and technologies such as no-tillage, drip irrigation and fertilizer application via irrigation water are employed by producers, enabling the State to become the third bulb producer in the Northeast Region.

Phosphorus $(\mathrm{P})$ is one of the most important and limiting nutrients in onion cultivation, although it is not the most absorbed by plants, especially when compared to nitrogen and potassium. It is also applied in greater quantity, according to the recommendations of fertilization in Brazil. Aguiar Neto et al. (2014) observed total P accumulation of 5.49 and $5.58 \mathrm{~kg} \mathrm{ha}^{-1}$ at the end of the cycle for the cultivars IPA11 and Texas Grano 502.

The doses of $\mathrm{P}$ applied to onion crop vary according to the producing region, due to specificities of soil, climate, cultivar and management. Mendes et al. (2008) recommends for this crop the application of 45 to $180 \mathrm{~kg} \mathrm{ha}^{-1}$ of $\mathrm{P}_{2} \mathrm{O}_{5}$, for the São Francisco Valley in Pernambuco, according to its availability in the soil. In Minas Gerais, the recommendation is 50 to $300 \mathrm{~kg} \mathrm{ha}^{-1}$ of $\mathrm{P}_{2} \mathrm{O}_{5}$ (Ribeiro et al., 1999). In São Paulo, the recommended values range from 80 to $300 \mathrm{~kg} \mathrm{ha}^{-1}$ of $\mathrm{P}_{2} \mathrm{O}_{5}$ (Trani et al., 2018). In the states of Rio Grande do Sul and Santa Catarina, the recommendation is 80 to $250 \mathrm{~kg} \mathrm{ha}^{-1}$ of $\mathrm{P}_{2} \mathrm{O}_{5}$ (Comissão de fertilidade do solo-RS/SC, 2016).

Regarding the response capacity of onion crop to phosphate fertilization, May et al. (2008) obtained yields

\footnotetext{
Submitted on November $5^{\text {th }}, 2020$ and accepted on January $21^{s t}, 2021$.

${ }^{1}$ This work is part of the first author's Master Dissertation

${ }^{2}$ Universidade Federal Rural do Semiárido, Departamento de Ciências Agronômicas e Florestais, Mossoró, Rio Grande do Norte, Brazil. luizricardo_5 @ hotmail.com; leilson@ufersa.edu.br; valdivia_sousa@hotmail.com; franciscoirael@hotmail.com; francisco.goncalves@ufersa.edu.br; gardeniavg @yahoo.com.br

*Corresponding Author: leilson@ufersa.edu.br
} 
of 64.8 and $72.0 \mathrm{t} \mathrm{ha}^{-1}$ respectively in the cultivars Optima and Superex with the application of $300 \mathrm{~kg} \mathrm{ha}^{-1}$ of $\mathrm{P}_{2} \mathrm{O}_{5}$. In the cultivar Bola Precoce, the application of $450 \mathrm{~kg} \mathrm{ha}^{-1}$ of $\mathrm{P}_{2} \mathrm{O}$ favored the yield of $71.4 \mathrm{t} \mathrm{ha}^{-1}$ (Hunger, 2013). The $\mathrm{P}_{2} \mathrm{O}_{5}$ dose of $130 \mathrm{~kg} \mathrm{ha}^{-1}$ promoted higher yield of marketable bulbs in the cultivars IPA 10 and IPA 11 (Resende et al., 2016). Novo Júnior et al. (2016) also obtained an increase in bulb yield of IPA 11 with the application of $168.75 \mathrm{~kg} \mathrm{ha}^{-1}$ of $\mathrm{P}_{2} \mathrm{O}_{5}$.

Due to the constant changes in Brazilian onion production, mainly in the adoption of new technologies such as the introduction of more productive hybrids, denser plantations, fertigation, among others, which increased the expected yields in most producing regions, it is necessary to conduct further research on nutrition and fertilization in order to meet the needs of the crop, providing the nutrients for the plant in a balanced way.

In this context, the objective of this study was to evaluate the agronomic performance of onion cultivars as a function of phosphate fertilization.

\section{MATERIALAND METHODS}

The experiments were conducted at the Rafael Fernandes Experimental Farm of the Federal Rural University of the Semi-Arid, located in the district of Alagoinha, rural area of the municipality of Mossoró, RN, Brazil ( $5^{\circ} 03^{\prime} 37^{\prime \prime}$ South latitude, $37^{\circ} 23^{\prime} 50^{\prime \prime}$ West longitude and approximate altitude of 72 meters), in the periods from July to October 2016 (Period 1) and from June to October 2017 (Period 2).

The soil of the experimental area was classified as Argissolo Vermelho Distrófico típico (Ultisol) (Rego et al., 2016). In the experimental areas, composite soil samples were collected in the $0-20 \mathrm{~cm}$ layer, and the results of chemical and physical analyses for Periods 1 and 2 were respectively: $\mathrm{pH}=6.20$ and $5.20 ; \mathrm{P}_{\text {(Menlich) }}=4.5$ and $4.4 \mathrm{mg} \mathrm{dm}^{-3} ; \mathrm{K}=53.5$ and $45.3 \mathrm{mg} \mathrm{dm}^{-3} ; \mathrm{Na}=3.3$ and $4.8 \mathrm{mg}$ $\mathrm{dm}^{-3} ; \mathrm{Ca}=1.17$ and $0.80 \mathrm{cmol}_{\mathrm{c}} \mathrm{dm}^{-3} ; \mathrm{Mg}=0.52$ and 0.50 $\mathrm{cmol}_{\mathrm{c}} \mathrm{dm}^{-3}$. The proportion of the fractions of sand, silt and clay was 900, 20 and $80 \mathrm{~g} \mathrm{~kg}^{-1}$ in Period 1 and 880, 50 and $70 \mathrm{~g} \mathrm{~kg}^{-1}$ in Period 2.

The experimental design was used in randomized blocks, in a 2 x 6 factorial scheme, with four replications. The treatments consisted of the combination of two onion cultivars (IPA11 and Rio das Antas) and six doses of $\mathrm{P}(0$; $60 ; 120 ; 180 ; 240$ and $300 \mathrm{~kg} \mathrm{ha}^{-1}$ of $\mathrm{P}_{2} \mathrm{O}_{5}$ ). Each experimental plot was composed of a $3.0 \times 1.0 \mathrm{~m}$ bed, with eight rows of plants, at spacing of $0.10 \mathrm{~m}$ between rows and $0.06 \mathrm{~m}$ between plants. The six central rows were considered as the usable area of the plot, disregarding two plants on each end, totaling an area of $1.93 \mathrm{~m}^{2}$.

Soil tillage was performed with plowing, harrowing and raising of the beds, followed by basal fertilization with the different doses of $\mathrm{P}$, in the form of triple superphosphate, applied broadcast and incorporated to $5 \mathrm{~cm}$ depth. The rest of the fertilization was performed via top-dressing fertigation. The fertilization adopted by onion producers in the state of Rio Grande do Norte was taken as reference, applying during the crop cycle $180 \mathrm{~kg} \mathrm{ha}^{-1}$ of N, $280 \mathrm{~kg} \mathrm{ha}$ ${ }^{1}$ of $\mathrm{K}_{2} \mathrm{O}, 47.50 \mathrm{~kg} \mathrm{ha}^{-1}$ of $\mathrm{Ca}$, and $13.77 \mathrm{~kg} \mathrm{ha}^{-1}$ of $\mathrm{Mg}$, in the forms of urea, potassium chloride, calcium nitrate and magnesium sulfate, respectively. $\mathrm{P}$ was applied only as basal according to treatments in the form of triple superphosphate. As a source of micronutrients, $18 \mathrm{~kg}$ ha${ }^{1}$ of zinc sulfate, $8 \mathrm{~kg} \mathrm{ha}^{-1}$ of boric acid and $1.62 \mathrm{~kg} \mathrm{ha}^{-1}$ of the commercial product Rexolin ${ }^{\circledR}$ were applied as basal.

Bulbs were manually harvested at 118 days after sowing (DAS) in Period 1 and at 131 DAS in Period 2. When $70 \%$ of the plants had lodged, irrigation was suspended, starting the curing process in the field with duration of 20 days. Then, the bulbs were cleaned, eliminating the leaves and roots. The evaluated characteristics were:

- $\mathrm{P}$ content in the diagnostic leaf $\left(\mathrm{g} \mathrm{kg}^{-1}\right)$ : the highest leaves of 20 plants from the usable area of the plot were collected in the middle of the crop cycle, at 55 DAS, according to the methodology proposed by Malavolta et al. (1997), and their P contents were analyzed following the methodology described by Tedesco et al. (1995).

- Plant dry matter (g plant $\left.{ }^{-1}\right)$ : at harvest, five plants of the usable area of the plot were collected, washed, placed in paper bags and dried in a forced air circulation oven with temperature regulated at $65^{\circ} \mathrm{C}$, until reaching constant weight.

- Classification of bulbs: performed based on bulb transverse diameter according to norms of the Ministry of Agriculture, Livestock and Food Supply (Brasil, 1995) - class 1 (diameter < $35 \mathrm{~mm}$ ); class 2 (diameter $35-49 \mathrm{~mm}$ ); class 3 (diameter 50-74 mm); and class 4 (diameter 75-90 $\mathrm{mm})$;

- Yield of marketable bulbs: determined by the total weight of bulbs with diameter $>35 \mathrm{~mm}$, without defects;

- Yield of non-marketable bulbs: obtained by the total weight of bulbs with diameter $<35 \mathrm{~mm}$ and/or double bulbs or bulbs with defects;

- Total yield of bulbs: obtained by the sum of marketable and non-marketable yields.

The economical dose of $\mathrm{P}$ was determined according to the methodology of Raij (1991) and Natale et al. (2011), calculated based on the derivative of the regression equation between the yield of marketable bulbs and the applied $\mathrm{P}$ doses, equaling to the exchange ratio $\left(\frac{d y}{d x}=a_{1}+2 a_{2}=\right.$ exchange ratio $)$. 
The most economical dose (x') was calculated by $x^{\prime}=$ (a1 - exchange ratio) / $2 \times\left(-a_{2}\right)$. The exchange or equivalence ratio was obtained from the average price of $\mathrm{R} \$ 1.37$ paid per kg of onion bulb in the State of Rio Grande do Norte at the time of the harvests of the experiments (Ceasa, 2017) and the cost of the $\mathrm{kg}$ of $\mathrm{P}_{2} \mathrm{O}_{5}(\mathrm{R} \$ 5.43)$ during the years 2016 and 2017. Thus, the exchange ratio used was the $\mathrm{kg}$ of $\mathrm{P} / \mathrm{kg}$ of onion sold, equal to $\mathrm{R} \$ 5.43$ / $\mathrm{R} \$ 1.37=3.96$.

The analyses of variance of the evaluated characteristics were performed separately for each experiment. Then, the experiments were jointly analyzed using the program Sisvar v5.3. (Ferreira, 2014). Regression analysis was performed for the quantitative factor ( $\mathrm{P}$ doses) and Tukey test at $5 \%$ probability level was applied for the qualitative factor (cultivars).

\section{RESULTS AND DISCUSSION}

The interaction between cultivar, $\mathrm{P}$ doses and periods was significant for plant dry matter and non-marketable yield. The $\mathrm{P}$ content in the diagnostic leaf, marketable yield and total yield was significantly affected by the double interactions between the factors studied.

The cultivars IPA 11 and Rio das Antas showed quadratic response for plants dry matter (PDM) in Period 1 , with estimated maximum values of 14.92 and $14.21 \mathrm{~g}$ plant $^{-1}$, at doses of 183.0 and $182.2 \mathrm{~kg} \mathrm{ha}^{-1}$ of $\mathrm{P}_{2} \mathrm{O}_{5}$, respectively. In Period 2, the cultivar IPA11 showed linear behavior, whereas a quadratic model fitted to the data of Rio das Antas, with estimated maximum values of 14.94 and $11.81 \mathrm{~g} \mathrm{plant}^{-1}$, at $\mathrm{P}_{2} \mathrm{O}_{5}$ doses of 300 and $199.75 \mathrm{~kg} \mathrm{ha}^{-1}$, respectively (Figures 1A and 1B). Aguiar Neto et al. (2014) observed PDM values close to those found in the present study, with about 16 and $23 \mathrm{~g} \mathrm{plant}^{-1}$ for IPA11 and 6.5 and $18 \mathrm{~g} \mathrm{plant}^{-1}$ for Texas Grano 502, in Petrolina and Baraúna, respectively, in soils with high $\mathrm{P}($ mehlich extractor $)$ contents. Also for the cultivar IPA 11, Novo Júnior et al. (2016) found a quadratic fit, with maximum PDM of $12.26 \mathrm{~g} \mathrm{plant}^{-1}(139.5 \mathrm{~kg}$ ha-1 of $\left.\mathrm{P}_{2} \mathrm{O}_{5}\right)$, in medium $\mathrm{P}($ mehlich extractor $)$ content soil.

In other vegetables, the responses were also positive for dry matter production as a function of phosphate fertilization, as in carrots (Assunção et al., 2016), beetroot (Silva et al., 2019) and potatoes (Fernandes et al., 2015).

The mean $\mathrm{P}$ contents in the diagnostic leaf as a function of $\mathrm{P}$ doses was described by a linear regression model, with estimated maximum values of 7.4 and $6.8 \mathrm{~g} \mathrm{~kg}^{-1}$, at the $\mathrm{P}_{2} \mathrm{O}_{5}$ dose $300 \mathrm{~kg} \mathrm{ha}^{-1}$, respectively for the cultivars IPA 11 and Rio das Antas (Figure 2). The leaf P contents, regardless of $\mathrm{P}$ doses, were within the adequate range of contents (2 to $5 \mathrm{~g} \mathrm{~kg}^{-1}$ ), according to Trani et al. (2014). However, in the treatment without $\mathrm{P}$ application, plants developed characteristic symptoms of deficiency, such as reduced growth of leaves and roots, abnormal development and delay in bulb maturity (Messele, 2016).

The reduction in plant growth (less dry matter), provided by $\mathrm{P}$ deficiency, probably favored a greater concentration of $\mathrm{P}$ in the leaves, in the treatment without application of phosphorus.

Silva et al. (2017), in soil with a medium contente of $\mathrm{P}\left({ }_{\text {mehlich extractor }}\right)$, observed a difference in behavior regarding the leaf $\mathrm{P}$ content of onion cultivars as a function of phosphate fertilization. The cultivars Red Creole, Baia Periforme and Primavera showed linear behavior, with estimated maximum values of $3.3,2.8$ and $2.8 \mathrm{~g} \mathrm{~kg}^{-1}$, respectively; obtained with $400 \mathrm{~kg} \mathrm{ha}^{-1}$ of $\mathrm{P}_{2} \mathrm{O}_{5}$, while for Diamatina the behavior was quadratic, with estimated maximum value of $3.5 \mathrm{~g} \mathrm{~kg}^{-1}$ at the $\mathrm{P}_{2} \mathrm{O}_{5}$ dose of $400 \mathrm{~kg} \mathrm{ha}^{-1}$. For the cultivar IPA 11, Novo Júnior et al. (2016) found a quadratic behavior with a maximum content of $6.3 \mathrm{~g} \mathrm{~kg}^{-1}$ (70.88 $\mathrm{kg} \mathrm{ha}^{-1}$ of $\mathrm{P}_{2} \mathrm{O}_{5}$ ).
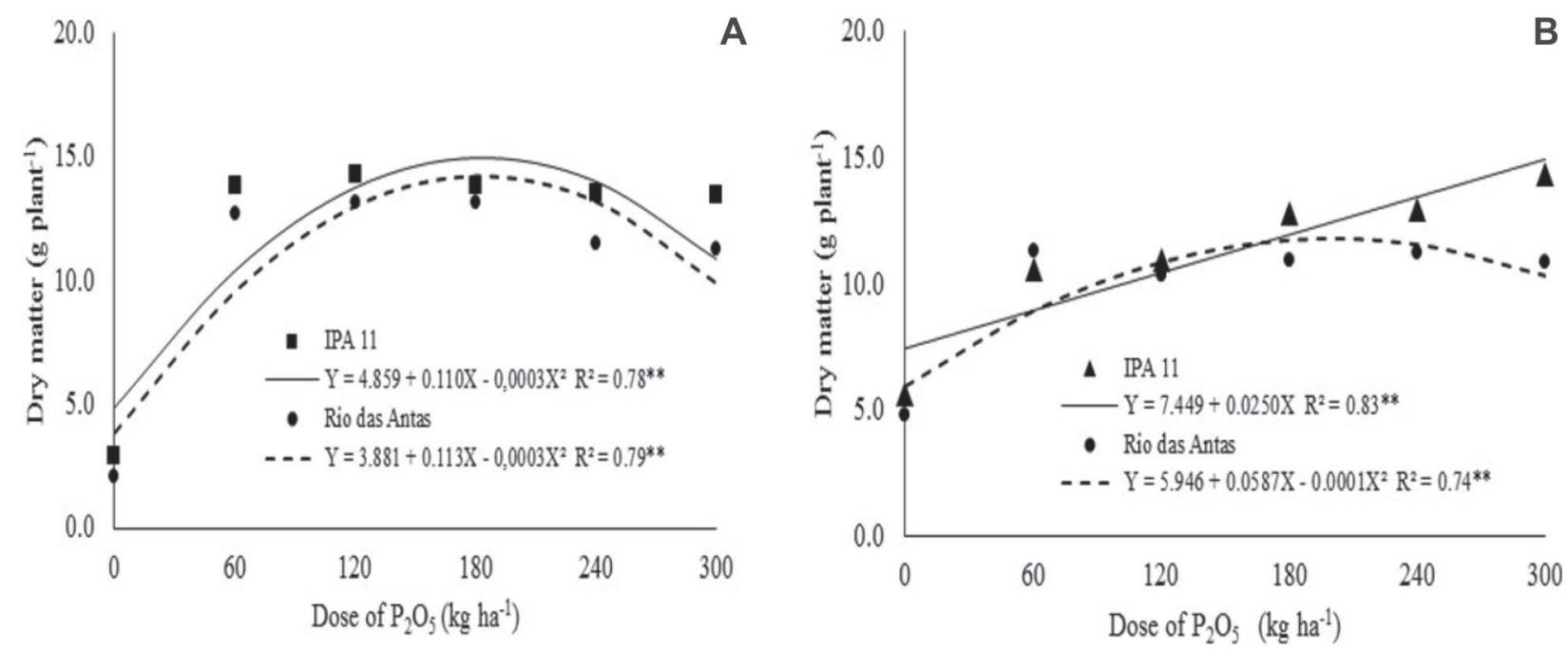

Figure 1: Plant dry matter as a function of phosphorus doses, in Period 1 (A) and Period 2 (B) of cultivation and onion cultivars. 
For the interaction between period and cultivar, the cultivars differed statistically in Period 1, with higher value for IPA 11. Between the periods, the P contents, regardless of the cultivars, were higher in Period 1. Only at the doses of 120,180 and $240 \mathrm{~kg} \mathrm{ha}^{-1}$ of $\mathrm{P}_{2} \mathrm{O}_{5}$, the cultivars differed statistically, with IPA11 being superior to Rio das Antas (Table 1).

The means of total yield (TY) of bulbs were described by the quadratic regression model for both cultivars. The estimated maximum values were 88.33 and $117.28 \mathrm{t} \mathrm{ha}^{-1}$, obtained with $\mathrm{P}_{2} \mathrm{O}_{5}$ doses of 216.3 and $205.2 \mathrm{~kg} \mathrm{ha}^{-1}$ for IPA11 and Rio das Antas, respectively (Figure 3A). The mean TY of the cultivar Rio das Antas was higher than that of IPA11 in both planting periods (Table 1).

The response of onion to $\mathrm{P}$ application can be explained by the low availability of $\mathrm{P}\left(4.4\right.$ and $\left.4.5 \mathrm{~g} \mathrm{dm}^{-3}\right)$ observed in the soil used in the experiments, because the effects of phosphate fertilization on crops are more pronounced in soils with low fertility.

The TY of the cultivar Rio das Antas was higher than that of IPA11 at all P doses, not differing significantly in the treatment without phosphate fertilization (Table 1). Such difference in response to phosphate fertilization found between the cultivars can be attributed to the superior genetic behavior of hybrids compared to openpollinated cultivars.

The results found in the present study were higher than the national average $\left(32.0 \mathrm{t} \mathrm{ha}^{-1}\right)$, from the Northeast Region (28.01 tha-1) (IBGE, 2018). This satisfactory yield achieved is due to the technologies applied along the study, such as the use of adapted cultivars, no-tillage, dense cultivation, weekly split fertilization applied via irrigation water and other cultural practices performed judiciously, whenever necessary. Santos et al. (2018) found similar results, applying $150 \mathrm{~kg} \mathrm{ha}^{-1}$ of $\mathrm{P}_{2} \mathrm{O}_{5}$, for the same cultivars and spacing with TY of 86.52, 96.52, 94.95 $\mathrm{t} \mathrm{ha}^{-1}$ and MY of $84.55,95.55,94.58 \mathrm{tha}^{-1}$ for the cultivars IPA11, Rio das Antas and Serena, respectively, in soil with a high $\mathrm{P}\left({ }_{\text {mehlich extractor }}\right)$ content. The yields were also higher than those found by Costa et al. (2008) for the cultivar Alfa Tropical (13.2 $\left.\mathrm{t} \mathrm{ha}^{-1}\right)$ and by Silva (2015) for the cultivars Red Creole (14.23 $\left.\mathrm{t} \mathrm{ha}^{-1}\right)$, Baia Periforme (21.90 t

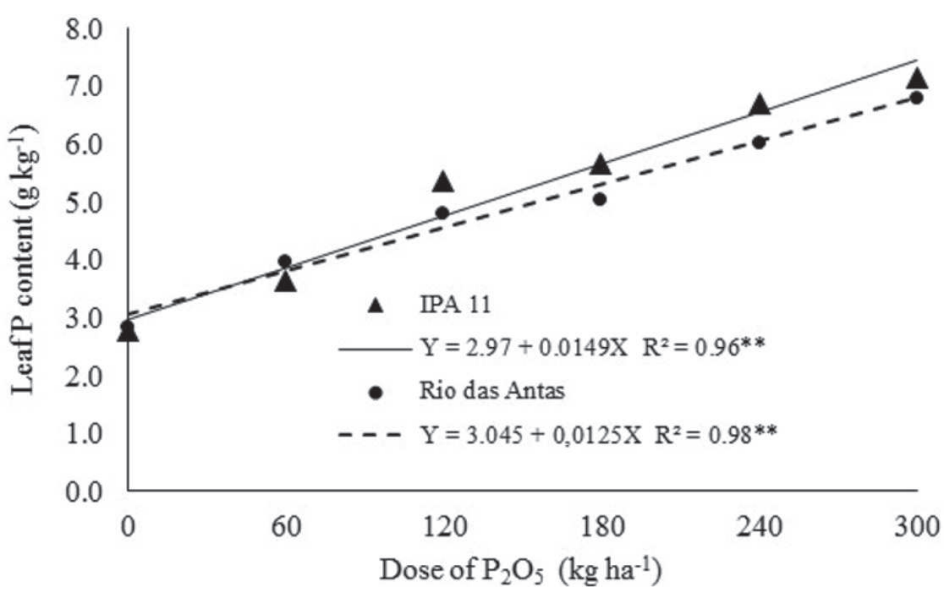

Figure 2: Phosphorus content in the diagnostic leaf as a function of phosphorus doses and onion cultivars.
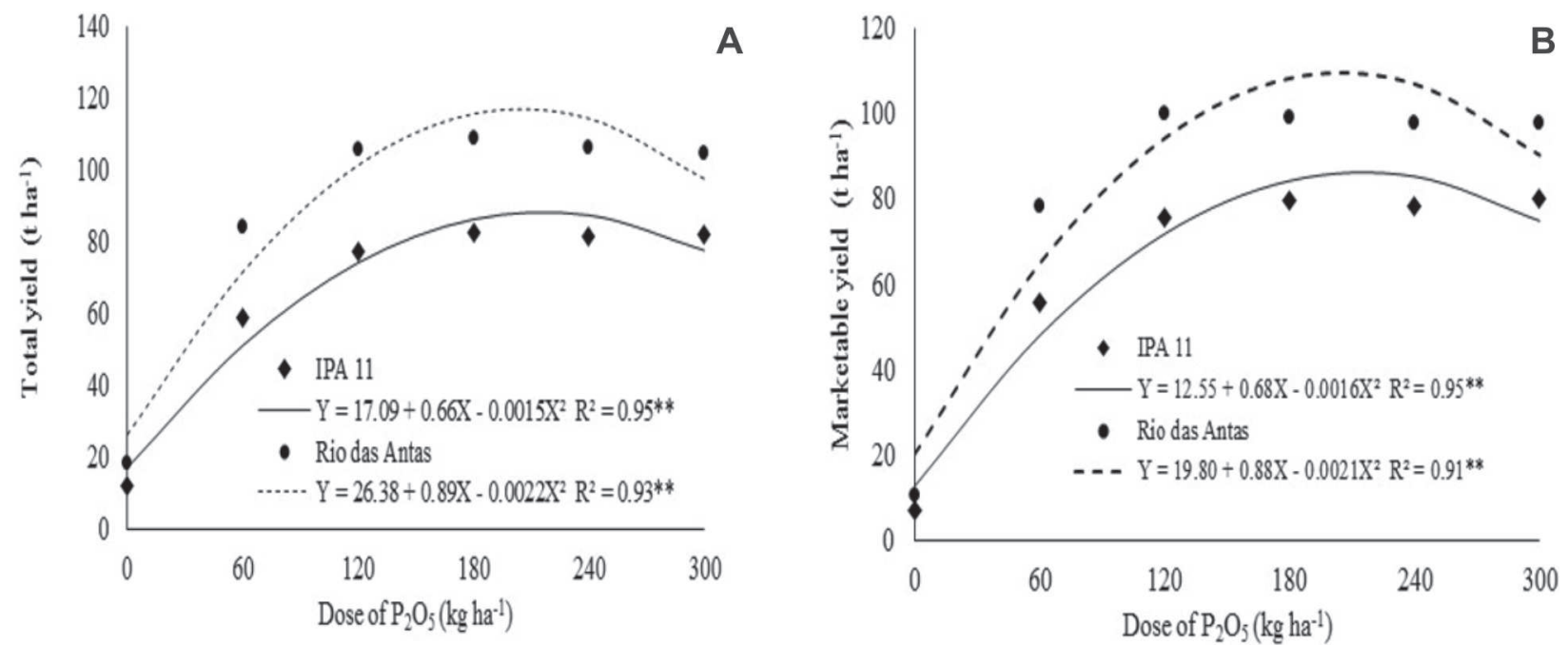

Figure 3: Total (A) and marketable (B) yields of bulbs as a function of phosphorus doses and onion cultivars. 
$\left.\mathrm{ha}^{-1}\right)$ and Primavera (21.61 $\left.\mathrm{tha}^{-1}\right)$ with the application of $400 \mathrm{~kg} \mathrm{ha}^{-1}$ of $\mathrm{P}_{2} \mathrm{O}_{5}$ (soils with medium $\mathrm{P}$ contents).

The marketable yield (MY), as observed for TY, showed a quadratic effect in response to phosphate fertilization, with estimated maximum values of 86.20 and $109 \mathrm{t} \mathrm{ha}^{-1}$ obtained with $\mathrm{P}_{2} \mathrm{O}_{5}$ doses 215.4 and $208.8 \mathrm{~kg}$ ha ${ }^{1}$, respectively, for the cultivars IPA11 and Rio das Antas (Figure 3A). From these doses, there was a reduction in MY in all cultivars. In the absence of phosphate fertilization, the MY of IPA 11 was $63.2 \%$ of Rio das Antas. However, the increments in MY, considering the estimated dose that maximized the MY compared to the treatment without $\mathrm{P}$ application, was approximately 587 and $450 \%$ respectively for IPA 11 and Rio das Antas.

The cultivar Rio das Antas was superior to IPA11 at all $\mathrm{P}$ doses, not differing significantly in the treatment without phosphate fertilization, and Rio das Antes was also superior in both planting periods (Table 1).

Resende et al. (2016), in soil with a medium contente of $\mathrm{P}\left({ }_{\text {mehlich extractor }}\right)$ observed MY in cultivars Franciscana IPA 10 (74.6 $\left.\mathrm{t} \mathrm{ha}^{-1}\right)$ and Vale Ouro IPA11 (76.1 $\left.\mathrm{t} \mathrm{ha}^{-1}\right)$, applying $135 \mathrm{~kg} \mathrm{ha}^{-1} \mathrm{P}_{2} \mathrm{O}_{5}$, similar yields to that found in the present study. Wamser et al. (2011), evaluating P doses and planting methods, observed in the heirloom onion cultivar Mercosul maximum MY at the $\mathrm{P}_{2} \mathrm{O}_{5}$ dose of $180 \mathrm{~kg}$ $\mathrm{ha}^{-1}$, corresponding to 26.9 and $23.6 \mathrm{t} \mathrm{ha}^{-1}$ using no-tillage and transplanting of seedlings, respectively (soil with medium $\mathrm{P}_{\text {(mehlich extractor) }}$ content).

For non-marketable yield (NMY) as a function of $\mathrm{P}$ doses in Period 1, the data were not described by any mathematical model, and the obtained means were 1.88 and $6.24 \mathrm{t} \mathrm{ha}^{-1}$ for the cultivars IPA11 and Rio das Antas, respectively. In Period 2, IPA11 showed quadratic behavior, with an estimated maximum of $7.27 \mathrm{tha}^{-1}$ at the
$\mathrm{P}_{2} \mathrm{O}_{5}$ dose of $0 \mathrm{~kg} \mathrm{ha}^{-1}$, while Rio das Antas obtained an average of $8.53 \mathrm{t} \mathrm{ha}^{-1}$ (Figures 4A and 4B).

Santos et al. (2018) obtained lower values of NMY when applying a P-dose of $150 \mathrm{~kg} \mathrm{ha}^{-1}$ in cultivars IPA11 (1.97 t $\left.\mathrm{ha}^{-1}\right)$, Rio das Antas (0.96 tha $\left.{ }^{-1}\right)$ and Serena $\left(0.37 \mathrm{t} \mathrm{ha}^{-1}\right)$ in soil with $15.59 \mathrm{mg} \mathrm{dm}^{-3}$ of P in the municipality of Mossoró/ RN. Novo Júnior et al. (2016), in the same municipality for the cultivar IPA11, observed decreasing linear behavior of NMY, with the lowest value $\left(0.36 \mathrm{tha}^{-1}\right)$ obtained at the $\mathrm{P}_{2} \mathrm{O}_{5}$ dose of $168.75 \mathrm{~kg} \mathrm{ha}^{-1}$. Values closer to those of the present study were found by Silva (2015) and Harms et al. (2015), 6.01 and $5.90 \mathrm{t} \mathrm{ha}^{-1}$.

The economical P dose for the highest marketable yield of onion was obtained through the regression equation of Figure 3B $\left(y=12.55+683.80 x-0.0016 x^{2}\right)$, for the cultivar IPA $11(683-3.96) /(2 \times 0.0016)=212.45 \mathrm{kgha}^{-1}$ of $\mathrm{P}_{2} \mathrm{O}_{5}$.

The expected revenue generated by this economical dose can be determined by the increment in bulb production of $79.09 \mathrm{t} \mathrm{ha}^{-1}$ (marketable yield at the most economical $\mathrm{P}$ dose of $86.20 \mathrm{t} \mathrm{ha}^{-1}$ minus the yield obtained in the treatment without phosphate fertilization, equal to $\left.7.11 \mathrm{t} \mathrm{ha}^{-1}\right)$. Subtracting the cost of the phosphate fertilizer, using onion as currency $(212.45 \mathrm{~kg} \times \mathrm{R} \$ 5.43=1,153.60$ (: $1.37)=842 \mathrm{kgha}^{-1}$ or $\left.0.842 \mathrm{tha}^{-1}\right)$, results in a revenue of $78.25 \mathrm{t} \mathrm{ha}^{-1}$ of bulbs, which is equivalent to a revenue of $\mathrm{R} \$ 107,202.50$ (78.250 $\left.\mathrm{kga}^{-1} \times R \$ 1.37\right)$.

Repeating the same process for the cultivar Rio das Antas, the most economical dose was $207.65 \mathrm{~kg} \mathrm{ha}^{-1}$ of $\mathrm{P}_{2} \mathrm{O}_{5}$, with the expected revenue of $97.53 \mathrm{tha}^{-1}$ of bulbs, which represents a revenue of $\mathrm{R} \$ 133,616.10$.

The most economical dose represents the amount of fertilizer to obtain the maximum revenue per area. However, in the present study, these values were very close to the maximum physical yield, with $98.6 \%$ and $99.4 \%$ for the respective cultivars, possibly due to the high yield achieved

Table 1: P content in the diagnostic leaf, marketable yield (MY) and total yield (TY) onion as a function of phosphorus doses, cultivars and growing periods

\begin{tabular}{|c|c|c|c|c|c|c|}
\hline \multirow{2}{*}{ Cultivar } & \multicolumn{2}{|c|}{$P$ content ( $\left.\mathrm{g} \mathrm{kg}^{-1}\right)$} & \multicolumn{2}{|c|}{ MY $\left(t\right.$ ha $\left.^{-1}\right)$} & \multicolumn{2}{|c|}{ TY (t ha-1) } \\
\hline & Period 1 & Period 2 & Period 1 & Period 2 & Period 1 & Period 2 \\
\hline IPA 11 & $5.86 \mathrm{Aa}$ & $4.55 \mathrm{Ab}$ & $64.34 \mathrm{Ba}$ & $61.14 \mathrm{Ba}$ & $66.22 \mathrm{Ba}$ & $65.09 \mathrm{Ba}$ \\
\hline Rio das Antas & $5.22 \mathrm{Ba}$ & $4.60 \mathrm{Ab}$ & $77.31 \mathrm{Ab}$ & 83.99Aa & $83.54 \mathrm{Ab}$ & $95.52 \mathrm{Aa}$ \\
\hline $\begin{array}{c}\operatorname{Dose}_{\mathrm{P}_{2} \mathrm{O}_{5}} \\
\left(\text { kgha }^{-1}\right)\end{array}$ & IPA11 & Rio das Antas & IPA 11 & Rio das Antas & IPA11 & Rio das Antas \\
\hline 0 & $2.77 \mathrm{a}$ & $2.84 \mathrm{a}$ & $7.11 \mathrm{a}$ & $10.66 \mathrm{a}$ & $12.01 \mathrm{a}$ & $18.29 \mathrm{a}$ \\
\hline 60 & $3.63 \mathrm{a}$ & $3.98 \mathrm{a}$ & $55.83 \mathrm{~b}$ & $78.45 \mathrm{a}$ & $58.78 \mathrm{~b}$ & $84.20 \mathrm{a}$ \\
\hline 120 & $5.36 \mathrm{a}$ & $4.79 \mathrm{~b}$ & $75.50 \mathrm{~b}$ & $100.07 \mathrm{a}$ & $77.13 \mathrm{~b}$ & $106.03 \mathrm{a}$ \\
\hline 180 & $5.65 \mathrm{a}$ & $5.05 \mathrm{~b}$ & $79.70 \mathrm{~b}$ & $99.23 \mathrm{a}$ & $82.42 \mathrm{~b}$ & $108.93 \mathrm{a}$ \\
\hline 240 & $6.70 \mathrm{a}$ & $6.03 \mathrm{~b}$ & $78.44 \mathrm{~b}$ & $97.71 \mathrm{a}$ & $81.31 \mathrm{~b}$ & $106.07 \mathrm{a}$ \\
\hline 300 & $7.14 \mathrm{a}$ & $6.79 \mathrm{a}$ & $79.89 \mathrm{~b}$ & $97.79 \mathrm{a}$ & $82.25 \mathrm{~b}$ & $104.67 \mathrm{a}$ \\
\hline
\end{tabular}

*Means followed by the same letters, lowercase in the row and uppercase in the column, do not differ statistically at $5 \%$ probability level by Tukey test. 
combined with the satisfactory average price practiced by the market at that time. However, this reduction in the application of the input without a significant reduction in yield generates economic and environmental gains, since phosphate fertilizers represent a non-renewable source that is essential for the maintaining agriculture at the current standards. Also, according to Raij (1991), based on the Law of Diminishing Returns, the most indicated fertilization is the one that provides the highest profit for the producer, therefore being the most economical.

The percentages of bulbs in classes $\mathrm{C} 1$ and $\mathrm{C} 2$ decreased with the increase in the $\mathrm{P}$ dose applied, regardless of the cultivar. For both classes, the maximum values were obtained without $\mathrm{P}$ application. On the other hand, the classes $\mathrm{C} 3$ and $\mathrm{C} 4$ increased with the P doses. The cultivar IPA 11 had the highest percentage of C3 $(81.96 \%)$ at a $\mathrm{P}_{2} \mathrm{O}_{5}$ dose of $240 \mathrm{~kg} \mathrm{ha}^{-1}$, but from $60 \mathrm{~kg} \mathrm{ha}^{-1}$ of $\mathrm{P}_{2} \mathrm{O}_{5}$, it was already more than $70 \%$. For Rio das Antas, the percentage of $\mathrm{C} 3$ was increasing up to the $\mathrm{P}_{2} \mathrm{O}_{5}$ dose of $300 \mathrm{~kg} \mathrm{ha}^{-1}(68.44 \%)$, but the values were lower than those obtained with IPA 11 (Table 2).

With the increase in $\mathrm{P}$ doses, there is a reduction in the yield of smaller bulbs ( $\mathrm{C} 1$ and $\mathrm{C} 2$ ), and increase in $\mathrm{C} 3$, which is favorable for onion, as bulbs of this class are preferred by consumers and have a better price in the market, almost twice those of the other classes.

Novo Júnior et al. (2016), studying different $P$ doses for the cultivar IPA11 also under the conditions of Mossoró$\mathrm{RN}$, obtained $75.96 \%$ of the total produced of C3 bulbs, applying $135 \mathrm{~kg} \mathrm{ha}^{-1}$ of $\mathrm{P}_{2} \mathrm{O}_{5}$. Resende et al. (2016) observed for $\mathrm{C} 2$ a linear reduction with the increase of $\mathrm{P}$ doses, and this value was on the order of $1.36 \%$ for each increment in the dose. The $\mathrm{P}_{2} \mathrm{O}_{5}$ dose $240 \mathrm{~kg} \mathrm{ha}^{-1}$ led to the lowest production of bulbs in this class (17.0\%), i.e., lower doses proportionally increased the production of small bulbs. With regard to $\mathrm{C} 3$, there was an inverse relationship, that is, a linear increase with the increase in $\mathrm{P}$ doses, with $1.8 \%$ in bulb production in this class for each increase in the dose, with a maximum of $83.5 \%$, thus showing that $\mathrm{P}$ besides contributing to yield improvement also contributes to the production of bulbs with larger diameter. Regarding the cultivars, the authors report that IPA 11 had average percentages of $\mathrm{C} 2$ and $\mathrm{C} 3$ of $8.0 \%$ and $92 \%$, respectively.

Obtaining larger bulbs, besides being directly related to the increase in yield and the genetic characteristics of the cultivar, also increases profitability, because bulbs with
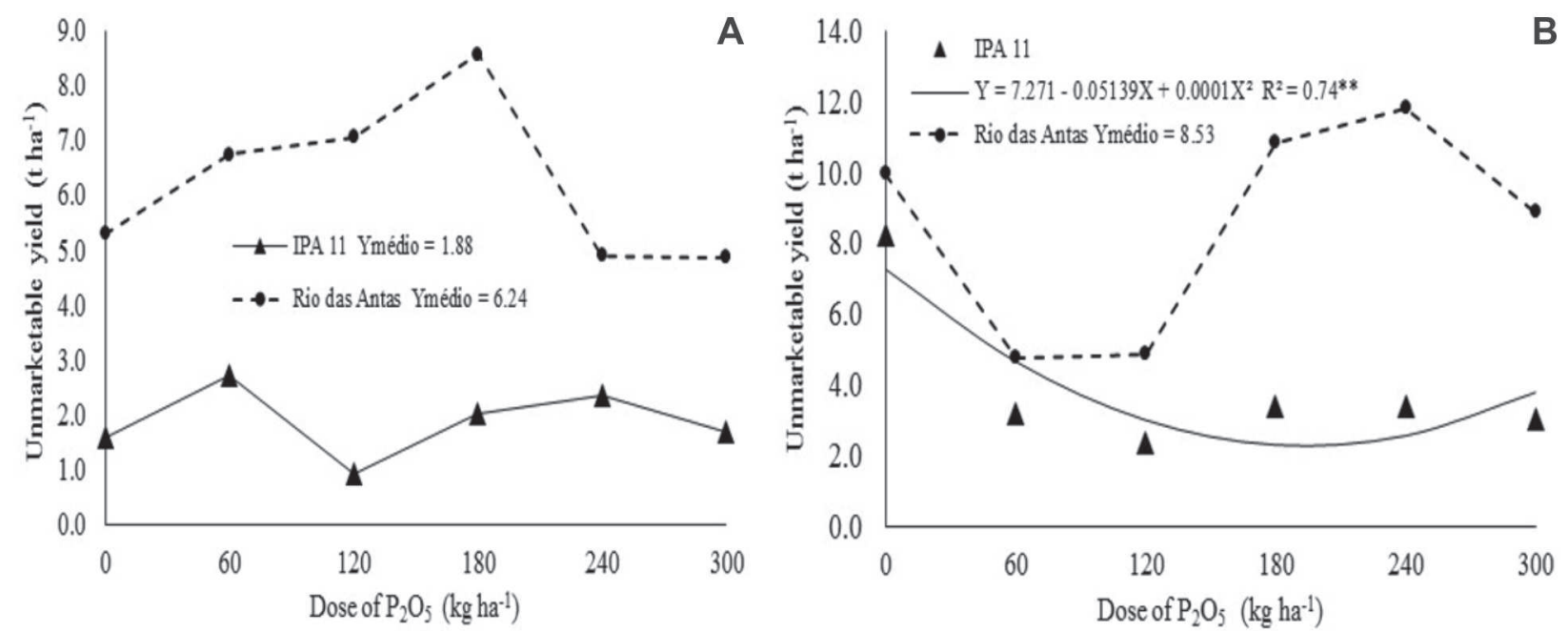

Figure 4: Non-marketable yield (NMY) as a function of phosphorus doses in Period 1 (A) and Period 2 (B) of cultivation and onion cultivars.

Table 2: Classification of onion bulbs as a function of phosphorus doses and onion cultivars into class 1 (C1), class 2 (C2), class 3 (C3) and class 4 (C4)

\begin{tabular}{|c|c|c|c|c|c|c|c|c|}
\hline \multirow{2}{*}{ Dose } & \multicolumn{2}{|c|}{ C1 (\%) } & \multicolumn{2}{|c|}{$\mathrm{C} 2(\%)$} & \multicolumn{2}{|c|}{$\mathrm{C} 3(\%)$} & \multicolumn{2}{|c|}{$\mathrm{C} 4(\%)$} \\
\hline & IPA11 & Rio dasAntas & IPA11 & Rio dasAntas & IPA 11 & Rio dasAntas & IPA 11 & Rio dasAntas \\
\hline 0 & 40.88 & 33.60 & 48.21 & 39.75 & 2.33 & 24.17 & 0.00 & 0.00 \\
\hline 60 & 4.96 & 3.25 & 22.80 & 13.22 & 72.35 & 53.25 & 3.13 & 24.38 \\
\hline 120 & 1.69 & 0.69 & 16.28 & 7.01 & 75.48 & 61.84 & 3.53 & 27.39 \\
\hline 180 & 2.49 & 0.81 & 16.21 & 6.23 & 74.58 & 52.99 & 8.51 & 29.90 \\
\hline 240 & 1.75 & 0.53 & 16.64 & 6.99 & 81.96 & 58.26 & 5.40 & 21.09 \\
\hline 300 & 1.49 & 0.39 & 14.46 & 5.45 & 77.76 & 68.44 & 5.69 & 18.94 \\
\hline Averag & 8.88 & 6.54 & 22.43 & 13.11 & 64.08 & 53.16 & 4.38 & 20.28 \\
\hline
\end{tabular}

Rev. Ceres, Viçosa, v. 68, n.5, p. 371-378, sep/oct, 2021 
diameter smaller than $50 \mathrm{~mm}$ have lower market value than bulbs with larger diameters (Kurtz et al., 2012).

The cultivar Rio das Antas had the highest percentage of bulbs in the class $\mathrm{C} 4$, compared to IPA 11 , with maximum values of 29.90 and $8.51 \%$ at the $\mathrm{P}_{2} \mathrm{O}_{5}$ dose of $180 \mathrm{~kg} \mathrm{ha}^{-1}$. Bulb of class C4 has a diameter of 75 to $90 \mathrm{~mm}$, which is considered large by the Brazilian consumer, so it has low market value and therefore the production in high percentage is not desirable.

\section{CONCLUSIONS}

The economical doses of phosphorus, associated with the maximum marketable yields of onion were estimated at 212.45 and $207.65 \mathrm{~kg} \mathrm{ha}^{-1}$ of $\mathrm{P}_{2} \mathrm{O}_{5}$, respectively for the cultivars IPA 11 and Rio das Antas. In general, the cultivar Rio das Antas was more productive than IPA 11, in the two growing periods.

\section{ACKNOWLEDGMENTS, FINANCIAL SUPPORT AND FULL DISCLOSURE}

The authors would like to thank CNPq (Conselho Nacional de Desenvolvimento Científico e Tecnológico) and CAPES (Coordenação de Aperfeiçoamento de Pessoal de Nível Superior) for their financial support.

The authors declare there is no conflict of interests in carrying the research and publishing the manuscript.

\section{REFERENCES}

Aguiar Neto P, Grangeiro LC, Mendes AMS, Costa ND, Marrocos STP \& Sousa VFL (2014) Crescimento e acúmulo de macronutrientes na cultura da cebola em Baraúna ( $R N$ ) e Petrolina (PE). Revista Brasileira de Engenharia Agrícola e Ambiental, 18:370-380.

Assunção NS, Clemente JM, Aquino LA, Dezordi LR \& Santos LPD (2016) Produtividade e eficiência de recuperação pela cenoura de nitrogênio, fósforo e potássio. Revista Caatinga, 29:858-865.

Brasil - Ministério da Agricultura, Abastecimento e Reforma Agrária (1995) Portaria n.529 de 18 agosto de 1995. DOU, 1/09/ 1995, Seção 1, p. 13.

CEASA (2017) Boletim informativo diário cotação em nível de atacado CEASA/RN. Available at: <http://www.ceasa.rn.gov.br/ conteudo.asp>. Accessed on: December 29, 2017.

Comissão de química e fertilidade do solo - RS/SC (2016) Manual de adubação e calagem para os Estados do Rio Grande do Sul e de Santa Catarina. $11^{\mathrm{a}}$ ed. Porto Alegre, Sociedade Brasileira de Ciências do Solo. 376p.

Costa ND, Araújo JF, Santos CAF, Resende GM \& Lima MAC (2008) Desempenho de cultivares de cebola em cultivo orgânico e tipos de solo no Vale do São Francisco. Horticultura Brasileira, 26:476-480.

Fernandes AM, Soratto RP, Moreno LA \& Evangelista RM (2015) Qualidade de tubérculos frescos de cultivares de batata em função da nutrição fosfatada. Bragantia, 74:102-109.

Ferreira DF (2014) Sisvar: A guide for its bootstrap procedures in multiple comparisons. Revista Ciência e Agrotecnologia, 38:109-112.
Harms MG, Dalla PM, Rezende BLA, Prestes AMC \& Dalazoana F (2015) Influência da densidade de plantas e do uso de fungicida nas doenças foliares e na produtividade de cebola. Horticultura Brasileira, 33:203-207.

Hunger H (2013) Produtividade e análise econômica da cultura da cebola sob diferentes densidades de plantio e níveis de adubação. Dissertação de mestrado. Universidade Estadual do Centro-Oeste, Guarapuava. 52p.

IBGE - Instituto Brasileiro de Geografia e Estatística (2018) Produção agrícola municipal 2018. Available at: <https:// sidra.ibge.gov.br/tabela/1612>. Acessed on: April 10, 2020.

Kurtz C, Ernani PR, Coimbra JLM \& Petry E (2012) Rendimento e conservação de cebola alterados pela dose e parcelamento de nitrogênio em cobertura. Revista Brasileira de Ciência do Solo, 36:865-876.

Malavolta E, Vitti GC \& Oliveira AS (1997) Avaliação do estado nutricional das plantas: princípios e aplicações. $2^{\mathrm{a}}$ ed. Piracicaba, Potafos. 319p.

May A, Cecílio Filho AB, Porto DRQ, Vargas PF \& Barbosa JC (2008) Acúmulo de macronutrientes por duas cultivares de cebola produzidas em sistema de semeadura direta. Bragantia, 67:507-512.

Mendes AMS, Faria CMB, Silva DJ, Resende GM, Oliveira Neto MB \& Silva MSL (2008) Nutrição Mineral e Adubação da Cultura da Cebola no Submédio do Vale do São Francisco. Petrolina, Embrapa Semiárido. 10p. (Circular técnica, 86).

Messele B (2016) Effects of nitrogen and phosphorus rates on growth, Yield, and quality of onion (Allium cepa L.) at Menschen fur demonstration site, Harar, Ethiopia. Agricultural Research \& Technology, 1:1-8.

Natale W, Rozane DE, Prado RM, Romualdo LM, Souza HAS \& Hernandes A (2011) Dose econômica de calcário na produtividade de caramboleiras. Revista Brasileira de Fruticultura, 33:1294-1299.

Novo Júnior J, Ribeiro RMP, Chaves AP, Sousa VFL, Grangeiro LC, Negreiros MZ, Marrocos STP \& Rodrigues GSO (2016) Effect of phosphorus fertilization on yield and quality of onion bulbs. African Journal of Agricultural Research, 11:4594-4599.

Raij BV (1991) Fertilidade do Solo e Adubação: Acidez e Calagem. Piracicaba, Editora Agronômica Ceres. 343p.

Rego LGS, Martins CM, Silva EF, Silva JJA \& Lima RNS (2016) Pedogênese e classificação de solos da fazenda experimental "Rafael Fernandes" no município de Mossoró-RN. Revista Caatinga, 29:1036-1042.

Resende GM, Costa ND \& Yuri JE (2016) Efeito de doses de fósforo na produtividade e armazenamento pós-colheita de dois cultivares de cebola. Revista Ceres, 63:249-255.

Ribeiro AC, Guimarães PTG \& Alvarez V VH (1999) Recomendações para o uso de corretivos e fertilizantes em Minas Gerais: $5^{\mathrm{a}}$ Aproximação. Viçosa, Comissão de fertilidade do solo do estado de Minas Gerais. 359p.

Santos JP, Grangeiro LC, Sousa VFL, Gonçalves FC, Franca FD \& Cordeiro CJX (2018) Performance of onion cultivars as a function of spacing between plants. Revista Brasileira de Engenharia Agrícola e Ambiental, 22:212-217.

Silva LL, Tavares AT, Nascimento IR, Milhomem KKB \& Santos JL (2017) Crescimento vegetativo e teor de fósforo em cultivares de cebola. Brazilian Journal of Applied Technology for Agricultural Science, 10:07-14.

Silva GA, Grangeiro LC, Sousa VFL, Silva LRR, Jesus PMM \& Silva JLA (2019) Agronomic performance of beet cultivars as a function of phosphorus fertilization. Revista Brasileira de Engenharia Agrícola e Ambiental, 23:518-523. 
Silva LL (2015) Desempenho agronômico e qualidade pós-colheita de cultivares de cebola sob níveis de adubação fosfatada em Dianópolis. Dissertação de mestrado. Universidade Federal do Tocantins, Gurupi. 74p.

Tedesco MJ, Gianello C, Bissani CA, Bohnen H \& Volkweiss SJ (1995) Análises de solo, planta e outros materiais. $2^{\text {a }}$ ed. Porto Alegre, UFRGS. 174p.

Trani PE, Breda Júnior JM \& Factor TL (2014) Calagem e adubação da cebola (Allium cepa L.). Campinas, Instituto Agronômico. $35 \mathrm{p}$.
Trani PE, Breda Júnior JM, Factor TL, Lina Júnior S \& Purquerio LFV (2018) Cebola. In: Trani PE, Raij B Van, Catarella H \& Figueiredo GJB (Eds.) Hortaliças: recomendação de calagem e adubação para o estado de São Paulo. Campinas, CATI. p.4143.

Wamser AF, Suzuki A, Mueller S, Gonçalves MM, Valmorbida J \& Becker WF (2011) Adubação fosfatada e potássica da cebola em área com resíduos de adubação do tomateiro. Agropecuária Catarinense, 24:86-88. 